\title{
Dr Barbara S. Neumann: Clay scientist and industrial pioneer; creator of Laponite ${ }^{\circledR}$
}

\author{
Kirill Shafran ${ }^{1}$, Christopher Jeans ${ }^{2}$, Simon J Kemp ${ }^{3 \text { (Orcid: 0000-0002-4604-0927) }}$ \\ and Kevin Murphy ${ }^{4, *}$ (Orcid: 0000-0002-8959-6765)
}

${ }^{1}$ BYK Additives, Widnes, UK

${ }^{2}$ Department of Earth Sciences, Cambridge University, UK

${ }^{3}$ British Geological Survey, Environmental Science Centre, Keyworth, UK

${ }^{4}$ Mineralogical Society of Great Britain \& Ireland, UK

*kevin@minersoc.org

In 2019, BYK Additives (Widnes, UK, www.byk.com) marked the $55^{\text {th }}$ anniversary of the discovery by Dr Barbara Zsusanna (Susanna) Neumann of the extraordinary product known as Laponite ${ }^{\circledR}$. The range of Laponite ${ }^{\circledR}$ products, developed in the UK during the early 1960s, is one of the first examples of truly nanodimensional materials manufactured on an industrial scale, at the time when the field of nanotechnology was only being hinted at (R. Feynman, 1959). These hectorite-like synthetic nano-clays with very unusual properties have been an enduring commercial success for the UK company that first patented and introduced them to the market, Laporte Industries, which is now a part of the BYK company. The Laponite ${ }^{\circledR}$ brand has proved tremendously popular with academic and industrial scientists worldwide, being cited in $>3000$ patents and $>2500$ published academic articles.

Few in the wider scientific community know about the history of these 'wonder' Laponite ${ }^{\circledR}$ materials, and the story of their creation by this pioneering industrial scientist (Fig. 1). Dr Neumann was passionate about clay science and mineralogy, and determined to succeed on an industrial scale. Even fewer are aware of her journey from wartime Hungary to Redhill, Surrey, UK and her determination to succeed in what was largely a man's world. A number of momentous turns of fate led to the discovery of Laponite ${ }^{\circledR}$ and other industrial minerals, still produced in thousands of tonnes and utilized around the world today.

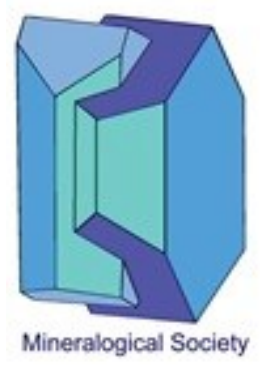

This is a 'preproof' accepted article for Clay Minerals. This version may be subject to change during the production process.

DOI: $10.1180 / \mathrm{clm} .2020 .35$ 


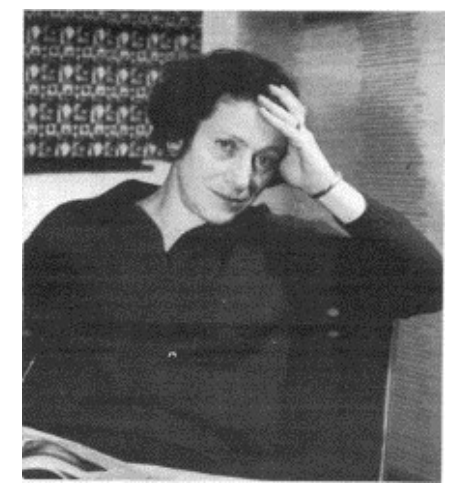

Figure 1. Dr Barbara Neumann at the Fuller's Earth Union (FEU) research laboratory (FEU became part of Laporte Industries in the 1960s).

Long-time friend and colleague, Christopher Jeans, takes up the tale here:

Barbara began her life in England and her job at the Fuller's Earth Union (FEU) in 1939 at a time of commercial flux for a long-established industry based on Ca-montmorillonitic earths. The earths were known only from a few localities, and they were being used up much faster than new deposits were being discovered. Their original use for fulling - the scouring and felting of woollen cloths- was over. The industry, now much contracted, was having to modify and develop its processing of the raw earth to discover and develop other uses for its absorptive and bonding properties. There were also the requirements of the war effort to enhance the production and quality of their clay products which were essential in the treatment of oils and for metal casting. Barbara Neumann was born in November 1914 and her first vivid memory was fleeing, at the age of 2 or 3 years, with her family from Szolnok, central Hungary during the First World War. She and her family had to move to Budapest to live with her grandmother. She remembered being carried on her father's shoulders and her sister Kata, who was four years older, being helped along beside them as they hurried to the station, taking only what they could carry. Life in Budapest was relatively poor, made even poorer when her father, a travelling button salesman, died when Barbara was just 19. She had just started at University - a significant achievement for a Jew in the Hungary of that time. Barbara studied physics. She would have studied chemistry but, due to anti-Semitic policies, that option was not available to her. Significant pressure was brought to bear on Barbara to give up her studies, but she persevered (with the support of a generous uncle) and achieved a degree and then a $\mathrm{PhD}$ in physics. She married her first husband, Gyorgy Emődi, around this time and they planned to travel abroad to escape the increasing racial tension in Hungary.

In what she described as a major stroke of luck, one of the samples of clay she had been working on as part of her $\mathrm{PhD}$ research (X-ray diffraction of clays) was a fuller's earth, with the address of the supplier, 'Fuller's Earth Union, Redhill, Surrey' on the packaging. With this serendipity, Barbara then showed her determination by writing to the manufacturers saying that she thought she could improve their product and .... would they therefore give her a job? She was 25 years old when she first visited England for the interview. Barbara recalls being taken out for a "very posh" dinner at the Savoy Hotel and remembers being embarrassed about her poor English at that time. She was offered an extra helping and responded "no thank you, I am fed up"! Nonetheless, she got the job.

She returned to Hungary to prepare for her move to England. She had hoped to travel back with her first husband, Gyorgy Emődi but he had no travel documents yet. She therefore made the journey alone, hoping he would be able to join her shortly afterwards. Sadly, as they were making plans, he was conscripted and died in an outbreak of typhus at the Front. So, Barbara travelled to England alone, knowing little English. She often 
spoke to her family about how welcoming people were in England. Shortly afterwards, in the immediate aftermath of the war, she met and married her second husband, Franz Neumann, who had also arrived in England as a refugee fleeing from Austria. They had two children: Vera and Peter. Barbara continued to work full-time at Fuller's Earth Union, which later became part of Laporte. Her daughter Vera later began to appreciate how unusual this situation was. Working mothers were a rarity in the $1950 \mathrm{~s}$; moreover, very few of them would have worked in a research laboratory. Nonetheless, Barbara strongly believed in women's selfsufficiency and independence, and certainly practised it. Vera notes that Barbara was proud and amused when the chair at a scientific meeting addressed the audience as "Lady and Gentlemen". Sadly, Franz died when Vera and Peter were of university age. With the help of friends, many from amongst the local Humanist community, and her beloved work, Barbara forged ahead with life. She worked hard, supported her family, knitted, sewed, cooked, exercised (“I only swim once a week - 40 lengths, but slowly”!). Her daughter Vera still recalls fondly a gentle approach to parenting taken by Barbara. She didn’t force her children to wear certain clothes, and they decided what way their own hair should be cut. A throwback to the stricter days of her own childhood perhaps...

C. Jeans: For a creative physicist, such as Barbara, it was one thing to improve a natural product as much as possible, but quite another to design and tailor an ideal material for a specific task. She must have had this ambition in the front of her mind, just waiting for the chance to put it into practice, once the pressure of war work was over. The question that set Barbara off on her hectorite/Laponite adventure had little to do with the raw material that the FEU extracted, but it had to do with an end use to which refined fuller's earth had been put since the $18^{\text {th }}$ Century, i.e. for medical and cosmetic purposes (Robertson 1986, pp. 147-159). The initial inquiry was from a cosmetics manufacturer about the availability and cost of purified hectorite. Hectorite is, like Ca-montmorillonite, a member of the smectite group of clay minerals. However, in contrast to the Camontmorillonite's dioctahedral structure, it is trioctahedral and contains appreciable amounts of lithium as a charge-forming moiety in its octahedral layer. Both the fuller's earths and the hectoritic clays are formed from the decomposition of glass-rich volcanic ash and tuffs. The difference is that the formation of the Camontmorillonite took place in an open marine environment where the concentration of lithium is very low $(0.17 \mathrm{mg} / \mathrm{L})$ whereas the hectorite developed in an alkaline lacustrine setting with a high lithium concentration. Today such lakes may have lithium concentrations of up to $3000 \mathrm{mg} / \mathrm{L}$. Hectorite was a rare and expensive clay mineral only available at that time in dwindling quantities from a mine near Hector, California USA. The combined cost of the raw hectorite clay and its purification was so high that it gave Barbara the chance and the commercial reason to see if such a clay mineral could be manufactured readily at a reasonable cost.

In the late $50 \mathrm{~s}$ and the early $60 \mathrm{~s}$, Laporte Industries were a major manufacturer of titanium dioxide pigments for paints. The most common paint systems at the time were organic solvent-based. Organically modified natural clays such as bentonites and hectorite were increasingly offered as thickeners for these paints. On the other hand, a new type of safer and more environmentally friendly, water-borne emulsion coatings and paints was coming to the fore in various industries (Croll, 2007). In order to accommodate titanium dioxide and other pigments in these new formulations, Laporte Industries tasked their research unit in Redhill, Surrey, with finding the right additives to provide rheology in these systems. Dr Neumann was one of the leading members of that team. Initially, a number of different inorganic minerals was tried - natural clays, synthetic hydrotalcites, 
and so on. However, they either required significant amounts of the additive in the formulation or imparted poor optical properties to the coatings due to the low intrinsic transparency of these materials.

A seminal paper by Granquist and Pollack published in 1960 detailed the preparation of a synthetic analogue of a natural fluorohectorite clay. The synthesis was conducted at atmospheric pressure, by simply boiling the predefined mixture of reagents for many days. Dr Neumann immediately started testing the proposed method in the laboratory. She soon realised that this route to synthesis was not industrially feasible and set about creating one that was. After several iterations, the first Laponite ${ }^{\circledR}$ material, which later became known as Laponite ${ }^{\circledR} B$, was born. In the corresponding filed patent, the synthesis, including starting materials and conditions, had been completely reworked and optimised for production on an industrial scale (Neumann, 1962).

Only an exceptional clay scientist of Neumann's standing could produce a commercially viable process for the synthesis of the first Laponite ${ }^{\circledR}$ material in such a short time. Using a wide range of methods including X-ray diffraction, thermal analysis and wet chemical methods, she proved the composition and structure of the first Laponite ${ }^{\circledR}$ to be that of the fluorohectorite mineral. She and her team also pioneered the use of the then nascent method of transmission electron microscopy (TEM) for the visualisation of Laponite $\mathbb{B}$ particles (Fig. 2); they were among the first scientists to apply this technique to a synthetic clay mineral. Laponite ${ }^{\circledR}$ remains a notoriously difficult specimen to analyse by microscopic methods (Rouse et al., 2004). The average diameter of the first disc-shaped Laponite ${ }^{\circledR}$ particles produced by Dr Neumann and her team was $\sim 60-80 \mathrm{~nm}$ (Fig. 2). The thickness of each particle was only $1 \mathrm{~nm}$, about three times the size of the component atoms. Some modern

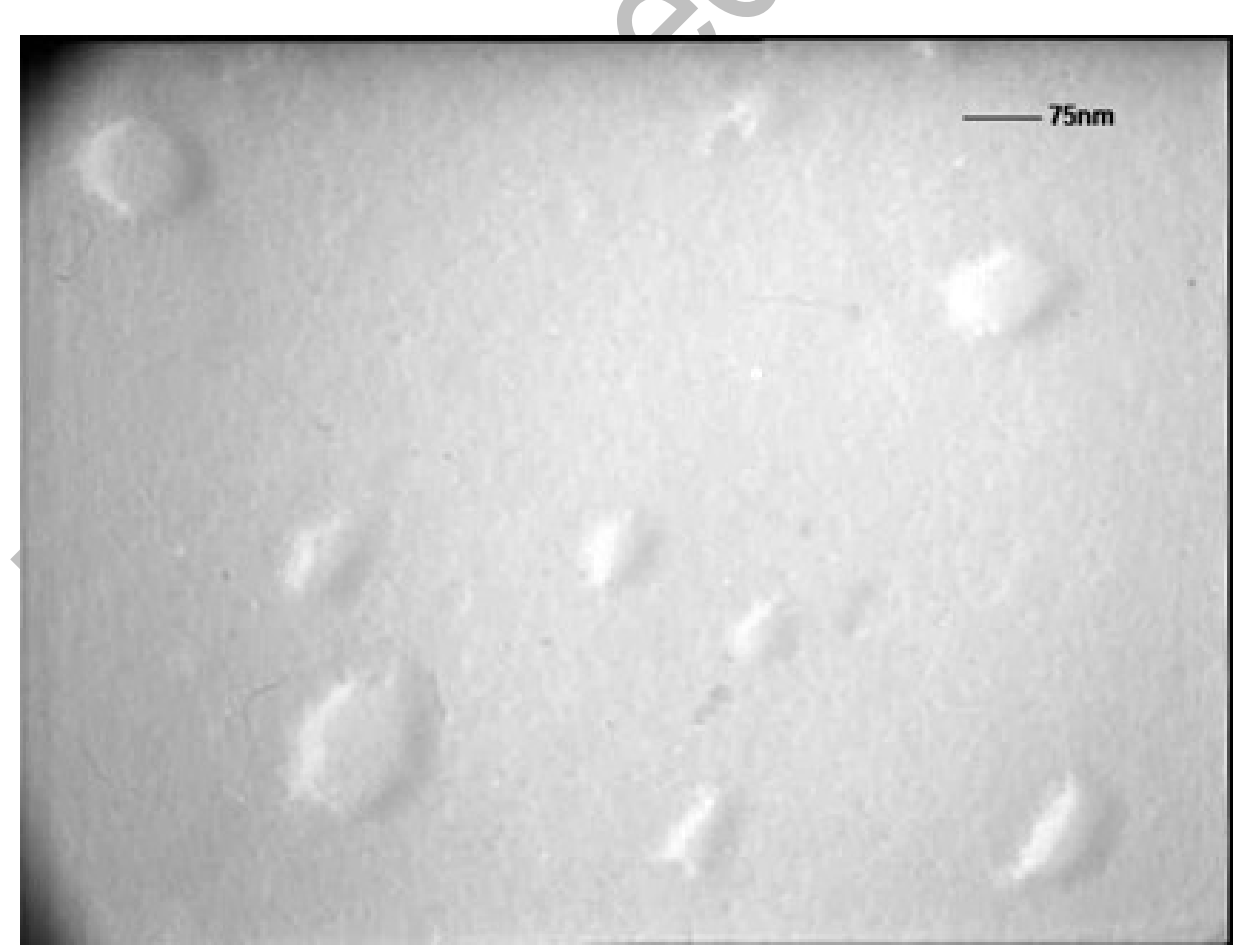

Figure 2. TEM image of Laponite ${ }^{\circledR}$ (fluorohectorite-like) produced using a 'shadowing' technique for BYK R\&D during the 1990s, similar to the images acquired by Dr Neumann's group.

grades of Laponite ${ }^{\circledR}$ contain even smaller nano-platelets, with average diameters of $20-30 \mathrm{~nm}$.

The mass production of Laponite ${ }^{\circledR}$ 'Type 1' (fluorohectorite-like synthetic clay) began in 1964 but the story of Laponite ${ }^{\circledR}$ didn’t stop there. Barbara continued to work in two directions. 
Firstly, she maintained her efforts to create a synthetic, fluoride-free version of hectorite. She realised, however, that to achieve this in the absence of fluoride-ions 'catalysing' the clay-formation reaction, she would need to employ higher pressures and temperatures. The lab work on Laponite ${ }^{\circledR}$ 'Type II' material involving hightemperature reactors started around 1964-1965. The corresponding patent was filed shortly afterwards (Neumann, 1966), and by 1967 the first hydrothermal production of Laponite ${ }^{\circledR} \mathrm{RD}$, the most common Laponite ${ }^{\circledR}$ material, began in Surrey. Later, in 1968, production moved to Stallingborough (near Grimsby, UK) and finally, in 1986, production relocated to Widnes, UK, where it continues today. As the lead developer of Laponite ${ }^{\circledR}$, Barbara was at the heart of the transfer of technology from the laboratory to industrial-scale manufacturing. Her meticulous approach, clear vision and great expertise in clay synthesis and characterization helped to achieve industrial scale-up over a very short timescale.

Secondly, Barbara worked hard to introduce Laponite ${ }^{\circledR}$ synthetic clays to a wider industrial and scientific

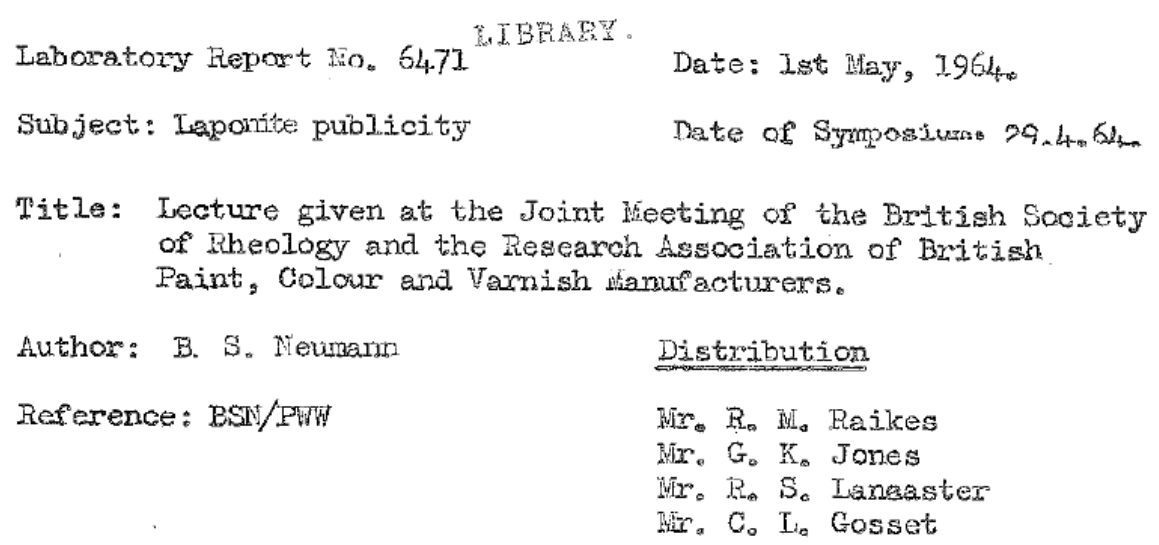

\section{Introduction}

The two societies named in the tithe arranged a joint meeting in the form of a one-day synposiun. BSN was asked in liovember 1963 by the organising secretary, kr. $R_{0} J$, Cole of the Paint Research Station; whether she could contribute a short paper on a subject of her own choice under the first section of the symposium dealing with the "Rheology in Pigment Dispersion and Paint Haking". After consultation with GKJ, ARP and CLG, it was docided to accept the invitation and use the opportunity to announce the availability and properties of Laponite for the first time. Sinee only a short

Figure 3. A fragment of the Dr Neumann's technical report detailing the announcement of Laponite ${ }^{\circledR}$ Type 1 availability to the public at the Joint Meeting of the British Society of Rheology and the Research Association of British Paint, Colour and Varnish.

audience, including specialists in products for the oil and gas industry, paints and coatings experts, as well scientists working in the broader area of rheology (the science of the fluid flow), and formulation science. Her presentation at the Joint Meeting of the British Society of Rheology and the Research Association of British Paint, Colour and Varnish manufacturers on the $29^{\text {th }}$ April 1964 (a fragment of which is shown in Fig. 3), is believed to be the official 'Birthday' and the beginning of the commercial success story of the Laponite ${ }^{\circledR}$ brand. From this point, Barbara further developed her second scientific passion (along with clay science and mineralogy) - the rheological applications of clays as additives to a variety of formulations and other purposes (Taylor and Neumann, 1968; Neumann and Sansom, 1970). At an early stage, Barbara spotted the exciting potential of Laponite ${ }^{\circledR}$ materials as powerful thickeners of aqueous rather than solvent-based formulations. 
Laponites ${ }^{\circledR}$ possess antistatic and barrier properties, are biologically and environmentally benign, and produce highly transparent suspensions and gels with thixotropic (shear-thinning) properties, important for many applications, such as paints and coatings (https://www.byk.com/en/product/additives-by-name/laponite). Laponite ${ }^{\circledR}$ particles can partially or completely replace oil-based surfactant molecules as stabilisers in Pickering emulsions. Their numerous functional benefits have since been applied in cosmetics and personal care products, in the agricultural, biomedical, papermaking, oil \& gas, and a great number of other industries.

After creating and developing the two main types of products in the Laponite ${ }^{\circledR}$ range, Barbara continued to work on clay synthesis. She created four different 'types' of Laponite $\AA$, two later, lesser-known 'types' included synthetic stevensite (a Li-free Mg-silicate clay) and synthetic nontronite (an Fe-silicate clay). She also experimented with other smectite minerals (i.e. swelling clays), e.g. saponite. Today, her publications, patents and technical reports still represent a real treasure trove and a great inspiration for the new generation of clay scientists.

Today, the manufacture of Laponite ${ }^{\circledR}$ retains significant similarities to the synthesis route originally proposed by Dr Neumann (Fig. 4), despite becoming a modern chemical production with state-of-the-art engineering and highly automated process control.

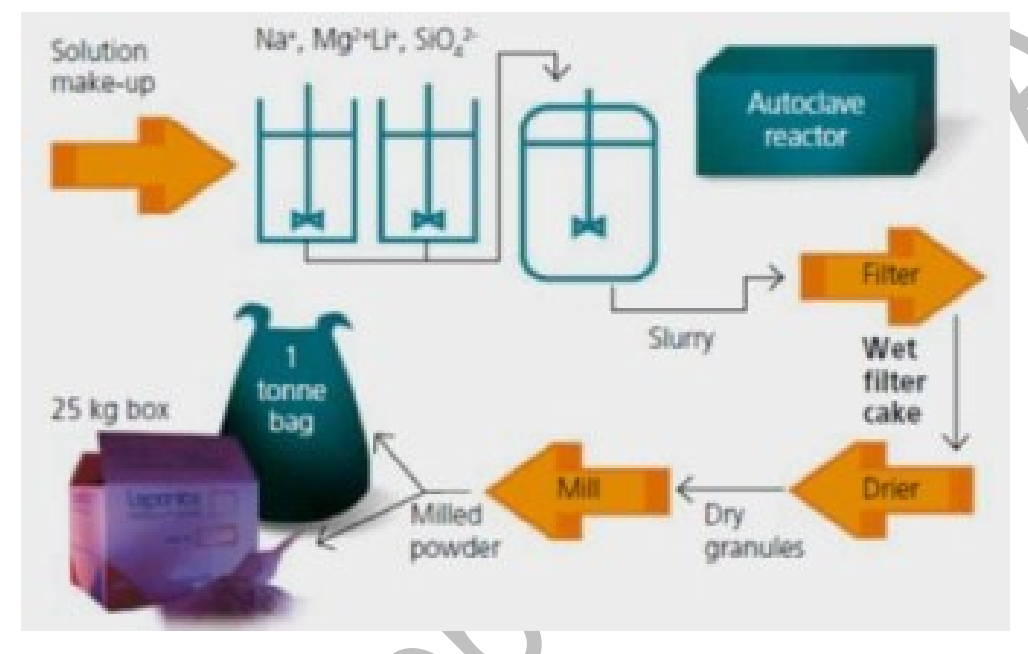

Figure 4. Schematic flowchart depicting the general process for making Laponite ${ }^{\circledR}$ (www.byk.com)

\section{Contributions to the Clay Minerals Group of the Mineralogical Society of Great Britain and Ireland}

Barbara was also a very active and enthusiastic member of the Clay Minerals Group (CMG) of the Mineralogical Society of Great Britain \& Ireland and served as its first, and, to date, only, female Chair from 1967-1969.

Through the CMG, Barbara developed an interest (in common with fellow CMG member, C. Jeans) in the origin of the Ca-montmorillonite in the British Mesozoic strata that formed the basis of the UK fuller's earth industry:

C. Jeans: What influence did the extensive Cretaceous volcanism of the Rockies have upon the origin of the Camontmorillonite in the British Fuller's earths? Prior to continental drift, the Rockies and western Europe were much closer. Montmorillonitic bentonites of Cretaceous age are abundant in North America; there is no doubt about their volcanogenic origin. In contrast, the origins of the English fuller's earths were contested energetically. Were they marine chemical precipitates or derived from the breakdown of volcanic ash? Argument favoured a non-volcanic source as there was no recorded volcanism of suitable age. For Laporte 
Industries, their origin was an important matter. The earths were stratigraphically very restricted to marine sediments of Aptian ( 112 Ma) and Bathonian ( 165 Ma) age and they were fast running out. What was the commercial future of an industry based on a natural but variable product that could not be replaced? Barbara and Derek Oliver [head of the Redhill and Bath operations] clearly realised the problematic future. Barbara ensured the funding of a two-year research post for Jeans, who clearly demonstrated a volcanogenic origin (Jeans et al., 1977) (Fig. 5).

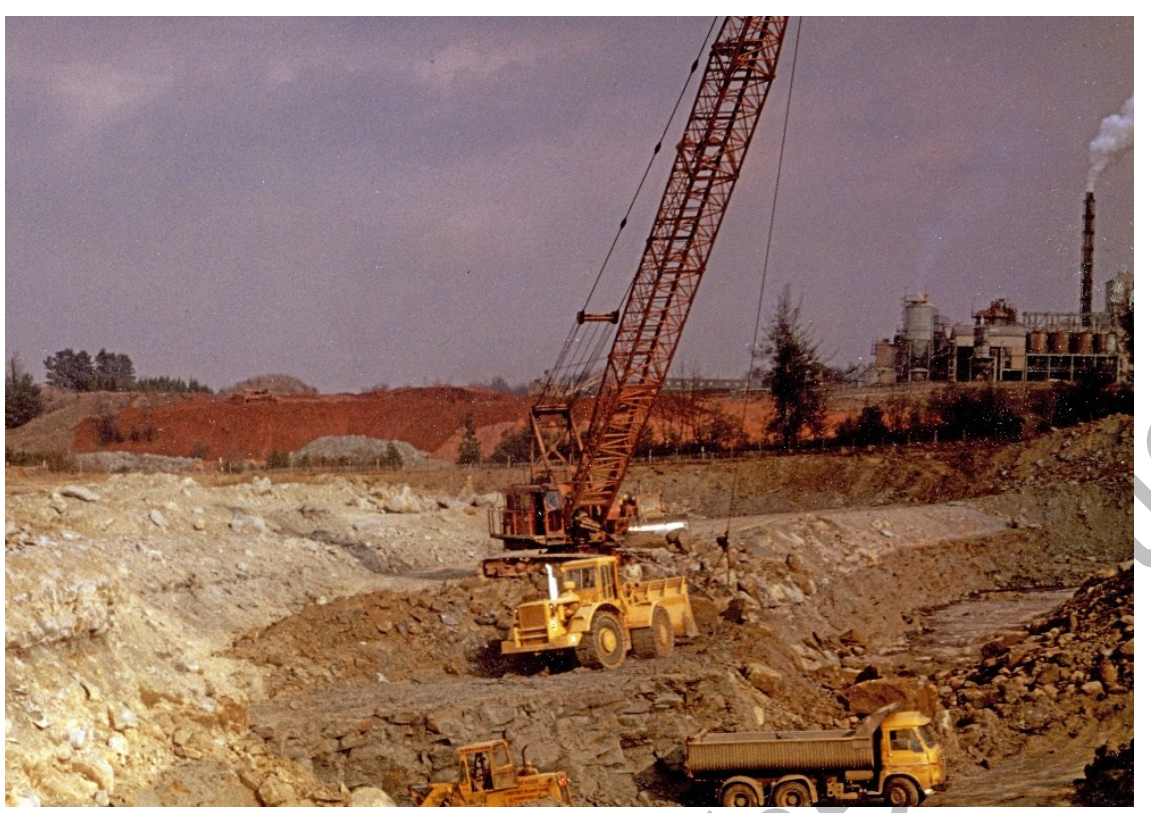

Figure 5. Fuller's Earth workings, Patterson Clay Pit, Redhill Surrey, UK.

A detailed history of fuller's earth was written by R.H.S. Robertson (1986, Fig. 6), founder member of the $\mathrm{CMG}$, and partial funding for the project came from Laporte Industries.

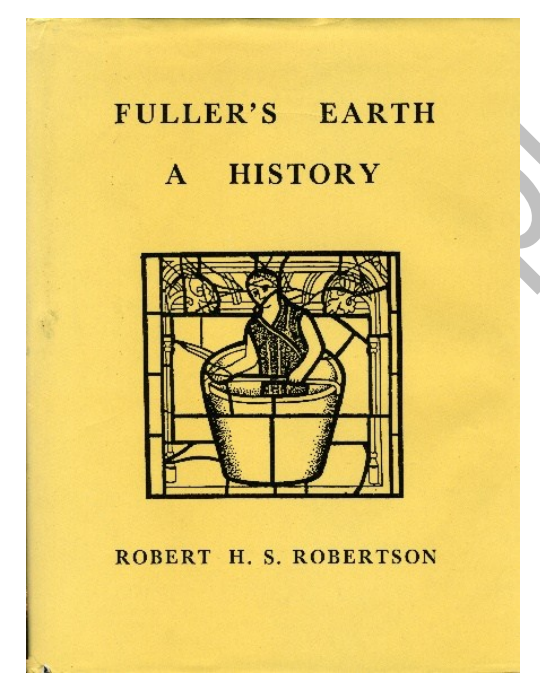

Figure 6. Fuller's Earth: A History, by Robert Robertson.

After five decades of success, the Laponite ${ }^{\circledR}$ synthetic mineral invented by Barbara has undergone a renaissance. New application opportunities have opened for this material in biomedicine, catalysis, nanoimaging, energy storage ( $\mathrm{Li}$ batteries), clay-polymer nanocomposites, advanced coatings and films. Scientists continue to invent new uses for Laponite ${ }^{\circledR}$, as well as using it as a model clay system to advance understanding of complex clay behaviour in aqueous suspensions and other colloidal systems. 
This success story would not have been possible without Dr Neumann. Industries and researchers using Laponite ${ }^{\circledR}$ today and the wider clay science community are deeply indebted to this talented industrial scientist for the work and discoveries she made.

Two important books about the history of clays published in recent decades both failed to mention Dr Neumann, a fact pointed out in a review of both (Jeans, 2009). So, it is appropriate that the Clay Minerals Group and BYK have undertaken to remember her now through this publication.

In her honour, the Mineralogical Society has decided to retitle its senior medal in her name. The first award will be made in 2022 .

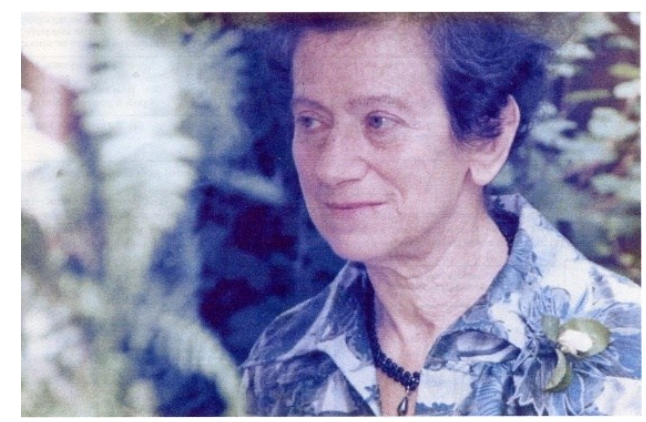

\section{Figure 7. Barbara Neumann.}

Barbara retired at 60 , as she had planned. She remained very active and took some consultancy work for Watts Blake and Bearne, making frequent visits to their china clay works in Cornwall. She also joined and/or organised numerous classes including geology, Spanish, English literature and philosophy as part of the University of the Third Age movement and remained a keen member for the rest of her life. Following a stroke, Barbara died in her $88^{\text {th }}$ year.

\section{Acknowledgements}

The authors are grateful to BYK for providing the photographic material presented here, and to Vera and Peter Neumann for much of the personal biographical information about Barbara.

\section{References}

Croll, S. Overview of Developments in the Paint Industry since 1930. In Modern Paints Uncovered: Proceedings from the Modern Paints Uncovered Symposium. Getty Conservation Institute, 2007, pp. 17-29.

Feynman, R. (1959) "There's Plenty of Room at the Bottom: An Invitation to Enter a New Field of Physics". Lecture at the annual American Physical Society meeting at Caltech on December 29, 1959.

Granquist, W.T. and Pollack, S.S. (1960) A study of the synthesis of hectorite. Clays and Clay Minerals, 8, $150-169$.

Jeans, C.V. (2009) Contrasting books on clay mineral science - how should they be judged? Acta Geodynamica et Geomaterialia, 6, 45-58.

Jeans, C.V., Merriman, R.J., \& Mitchell, J.G. (1977) Origin of the Middle Jurassic and Lower Cretaceous Fuller's Earths in England. Clay Minerals, 12, 11-44.

Neumann, B.S. (1962) UK Patent GB1054111. Improvements in or relating to Synthetic Clay-Like Minerals. Filing Data: 26/06/1962.

Neumann, B.S. (1966) UK Patent GB1213122. Clays.

Neumann, B.S., Taylor J. (1968) Nature of synthetic swelling clays and their use in emulsion paint. Journal of the Oil and Colour Chemists' Association, 51, 232-53. 
Neumann, B.S., Sansom, K.G. (1970) Study of gel formation and flocculation in aqueous clay dispersions by optical and rheological methods. Journal of the Society of Cosmetic Chemists, 21, 237-58.

Rouse J.H., White S.T., Ferguson G.S. (2004) A Method for Imaging Single Clay Platelets by Scanning Electron Microscopy. Scanning, 26, 131-134. 